\title{
Kan man være lykkelig som syk?
}

\author{
Det er strevsomt å leve det perfekte liv. Sykdom kan bli et pusterom og gi tilværelsen \\ en ny retning.
}

Selvsagt kan man være lykkelig som syk. Alle sykdommer er ikke like plagsomme, og ved god omsorg og pleie kan det være direkte behagelig å bli syk. Fra å være arbeidsfør, men sliten og hardt presset i jobben kan tilværelsen plutselig bli direkte munter. Dertil er det kjekt å få alles oppmerksomhet for en tid. Hvis derimot sykdommen er smertefull og man føler seg dårlig, kan det bli ganske vondt å være pasient.

Idéhistorikere, filosofer og psykologer har i mange år vært opptatt av et beslektet problem: En vanlig tilværelse i samfunnet vårt kan være direkte plagsom, stressende og gi store påkjenninger. Sigmund Freud skrev i sin tid en hel avhandling om det han kalte «ubehaget i kulturen» (1), og der var verdensbildet ikke noe positivt. Under tittelen Lykkelig som syk ble det for et år siden skrevet om et møte i tankesmien Civita, der det ble hevdet at i Norge er vi overlesset med leger som sammen med andre faggrupper - prøver å ta unna et umettelig behov for hjelp til stadig mer diffuse lidelser (2). Under tittelen Kulturmenneskets byrde og sykdommens velsignelse disputerte den norske idéhistorikeren Monica Wegling for den filosofiske doktorgraden ved Norges teknisk-naturvitenskapelige universitet (3). Foruten å belyse fordelene ved å være syk reiste hun spørsmålet om medisinsk utredning og intervensjon kunne ha en selvstendig funksjon uavhengig av det kurative. Med andre ord kan det å bli ristet og gjennomgått i helsevesenet ha positive effekter som går langt utover å lindre det man opprinnelig kom og klaget over (4).

I denne debatten er det viktig å trekke fram en liten artikkel som den danske praktiserende legen Jørgen Hannibal i 1989 skrev i Pulsen, et blad for danske allmennleger. At det kan være positivt å bli betraktet som syk og få alles oppmerksomhet, gir selvsagt en stor gevinst. Men Hannibal viste gjennom flere pasienthistorier at alvorlig sykdom kunne vekke pasien- ten til å se med nye øyne på tilværelsen. Overfor alvorlig fare ser man bedre hva som har verdi i livet og hva som ikke har verdi. Etter alvorlige lidelser som hjerteinfarkt har omtrent en tredel av pasientene bedre livskvalitet enn før (4). Man legger om til en mindre stressende tilværelse med mer nærhet til familie og venner. Da Hannibal selv ble alvorlig syk, gikk han ned i arbeidstid og begynte å spille fløyte. Musikk kan i seg selv være helsefremmende.

Derfor må vi aldri glemme at alvorlig sykdom er også et eksistensielt spørsmål, ikke bare et terapeutisk. Noen modnes gjennom sykdom så de får innsikter de ikke hadde før. Dertil kommer at samfunnet i seg selv til tider er ganske «sykt». Kan vi verken helbrede det og heller ikke vår egen dype følelse av ubehag som vanlige borgere, da kan en liten sykdom, om den ikke er altfor vond, ha direkte helbredende effekt på en plagsom og smertefull normal tilværelse.

\section{Ole Didrik Lærum \\ ole.laerum@gades.uib.no}

Ole Didrik Lærum (f. 1940) er professor (adj.) ved Københavns Universitet og tidligere professor ved Universitetet i Bergen.

\section{Litteratur}

1. Freud S. Ubehaget i kulturen. Oslo: Cappelen, 1993.

2. Rossavik F. Lykkelig som syk. Bergens Tidende 31.5.2012.

3. Wegling M. Kulturmenneskets byrde og sykdommens velsignelse. Kan medisinsk utredning og intervensjon ha en selvstendig funksjon, uavhengig av det kurative? Doktoravhandling. Trondheim: Norges teknisk-naturvitenskapelige universitet, 2011

4. Lærum E. Frisk, syk eller bare plaget? Innføring i medisinsk nøkkelkunnskap. Bergen: Fagbokforlaget, 2005.

\section{Positiv sygdom}

Jørgen Hannibal: Positiv sygdom. Pulsen (Nyt fra Praktiserende Læger) 1989; 4: 1-2.

Jørgen Hannibal, praktiserende lage

Læger er opdragede til at opfatte sygdom som en fjende. Det afspejles i sprogbrugen: Sygdomsangreb. Ramt af sygdom. Slå sygdom på flugt. Bekæmpe sygdom.

Sygdom kan også indeholde postitive muligheder. Give større glæde ved livet. Give anledning til værdifulde ændringer i et menneskes tilværelse.
Et skandinavisk lægetidsskrift bringer interview af 84 mandlige patienter $12-21$ uger efter acut blodprop i hjertet.

$33 \%$ beskrev en forbedret total livssituation.

Mere end $50 \%$ rapporterede øget fysisk aktivitet, nedsat fedt- og kalorieindtagelse og nedsat oplevelse af stress på arbejde.
$60 \%$ havde nedsat/ophørt tobaksforbrug.

$20 \%$ havde nedsat alkoholforbrug.

$50 \%$ oplevede større taknemlighed for at være i live, for at have familie, livsglæde, hobbier og et godt helbred. 


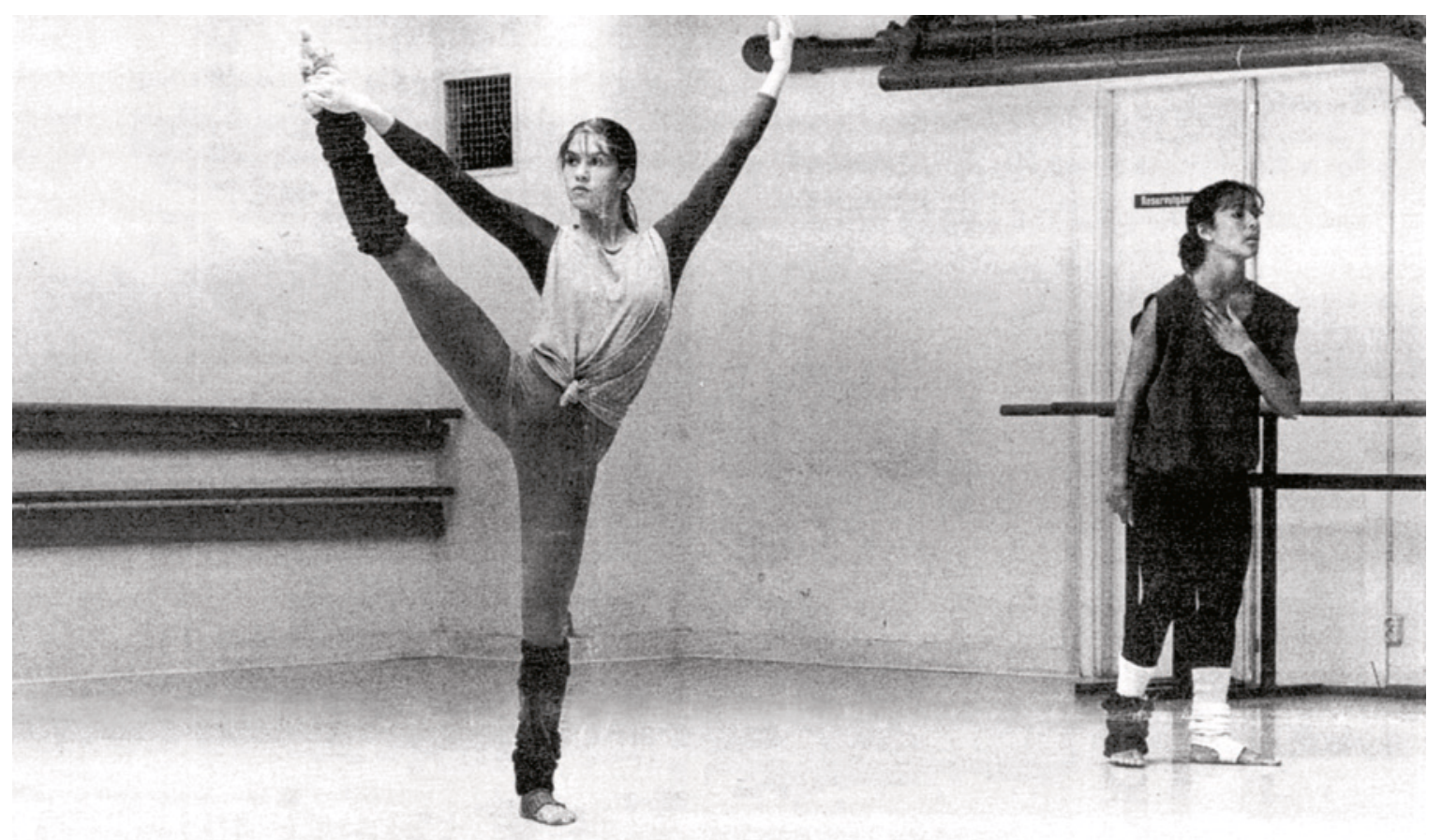

Walter Hirsch, Billedhuset

\section{Det bedste i livet}

For 8 år siden mødte jeg første gang den opfattelse, at et alvorligt sygdomsforløb kan indeholde noget positivt. Det skete på et efteruddannelseskursus i hjertesygdomme. En kollega fortalte, at han havde haft en blodprop i hjertet. Han havde oplevet det som noget af det bedste, der var hændt $i$ hans liv. Før blodproppen: Stor enkeltmandspraksis med vagtforpligtelse. Efter blodproppen: Kompagniskabspraksis med næsten samme patienttal og færre vagter. Tid til fisketure, som han nød med god samvittighed.

Et par år senere oplevede jeg sygdom på egen krop, «Mb.Hodgkin stad. I a.», lymfekræft i 1. stadium. Sygeorloven gav tid til overvejelser over mulige årsaker til sygdommens opståen. Jeg fandt grund til at ændre mine raktionsmønstre i forhold til omverdenen og i forhold til mig selv. Efter sygeorloven fik jeg nedsat arbejdstid. Når arbejdet havde fået sin del, havde jeg stadig energi til rådighed, blandt andet til at lære at spille fløjte.

Senere har jeg været i kontakt med mange patienter, som har oplevet noget positivt $i$ et alvorligt sygdomsforløb.

En 40-årig mand med blodmangel af uforklarlig årsag. Behandling: fjernelse af milten. Hans egen konklusion var, at sygdommen havde noget med hans stressede livsførelse at gøre. Han tog hele sin tilværelse op til revision sammen med familien. De solgte et stort parcelhus, flyttede til en lejlighed nærmere arbejdspladsen, og han gik ned i arbejdstid. «Lægerne er utroligt dyg- tige» var hans kommentar, «men det er nu mig selv, der har ansvaret for mit liv».

En 55-årig mand blev opereret for kræft i tyktarmen. Sygdommen fik ham blandt andet til at arbejde på at ændre sin personlige adfærd. «Bare jeg dog havde fået den kræft («kraft»?) for længe siden», bemærkede han.

En stresset forretningsmand var bekymret over tilbagevendende anfald. De bestod i diffuse muskelsmerter, almen træthed og madlede. De optrådte med uregelmæssige mellemrum 3-4 gange årligt. Han selvbehandlede med sengeleje $2-3$ dage med dynen trukket langt op over hovedet. Det lykkedes ham at omdefinere tilstanden. Han lærte at opfatte et anfald som kroppens meddelelse om, at grænsen for ydelse var overskredet. Anfaldet blev derfor en forbundsfælle. Senere blev han bedre til at forebygge.

Vi er medlemmer af et samfund, som er præget af en filosofi om konstant vækst. Der lægges stor vægt på succes på det materielle plan. Du skal klare dig godt i arbejdssituationen, have penge nok til at skaffe dig prestigegivene materielle goder, have et smukt og lydefridt familie- og fritidsliv, kunne holde ferie de rigtige steder, klæde dig i det rigtige tøj o.s.v.

Det koster blod, sved og tårer at leve op til disse idealer. Angsten, usikkerheden og fortvivlelsen kender alle mennesker til. De er helt naturlige følelser, men de må ikke udtrykkes. Store områder af den menneskelige natur er henvist til en skyggetilværelse.

\section{Helheden}

Betragt det kinesiske yin/yang symbol og den filosofi, det udtrykker. Cirklen angiver helhed. Helheden er sammensat af modsætninger. Den bølgede linie er udtryk for en dynamisk ligevægt mellem delene. De to pletter angiver, at hver del indeholder sin modsætning.

Et menneske er også en helhed sammensat at dele, af modsætninger, i dynamisk balance. Ingen del kan eksistere uden sin modsætning. Vi er glade og kede af det, vi elsker og hader, vi er tilfredse med os selv og usikre på os selv, og vi er syge og raske.

Kultur og normer tillader os kun at vise de lyse sider. Det forstyrrer balancen. Følelser gnaver i sulet, når de ikke får mulighed for at komme til udtryk. Det kan give anledning til allehånde somatiske og psykiske symptomer.

Vi er opdraget til først og fremmest at opfatte symptomer som udtryk for sygdom. Læger skal udføre mekaniske undersøgelser, stille diagnoser og behandle.

Måske skulle vi i større udstrækning søge efter de meddelelser, der ligger i symptomerne og gøre det, inden vi sætter undersøgelsesapparatet i gang. Det vil kræve mere tid i en vis fase. Det vil være tids- og ressourcebesparende på langt sigt. Det vil give færre lidelser, udløst af lægeundersøgelser og lægebehandling.

Det vil give os alle en større oplevelse af personligt ansvar og aktiv medvirken i livet. 